\title{
Law Enforcement to the Mining Crime of Class of C Without Permission Under Law No. 4 Year 2009 On Mineral Mining and Coal
}

\author{
Sabungan Sibarani \\ Law Faculty \\ Borobudur University \\ Jakarta, Indonesia \\ ssibarani01@gmail.com
}

\begin{abstract}
This paper aims to find solutions related to law enforcement to the mining crime of class of $\mathrm{C}$ without permission under Law No. 4 years 2009 on Mineral Mining and Coal. The handling of unlicensed Mining Permit cases that occurred in several regions in Indonesia has been proven by several cases processed and already transferred to the prosecutor's office for trial in some first instance courts or even at the level of the supreme court with the violated Article is Article 158 of Law No. 4 of 2009 on Mineral and Coal Mining juncto Article 109 juncto Article 116 of Law Number 32 Year 2009 on the Environment juncto Article 55, 56 paragraph (1) for 1 of Criminal Code. The application of material criminal provisions to cases of mining crimes without permission and without environmental permit is in accordance with the applicable law, based on legal facts found at the time of the investigation, whether in the form of witness statements and with the evidence and the recognition of the suspect all of which are in contravention of the article in the conjecture so that the Police have conducted an investigation and subsequently delegated to the Prosecutor for the prosecution process.
\end{abstract}

\section{Keywords - law enforcement, Illegal Mining}

\section{INTRODUCTION}

The mining law is never separated from the environment part is the grace of God Almighty that must be preserved and developed ability in order to remain a source of life support for humans and other living things for sake continuity and improvement of quality of life itself. Today, environmental crimes are frequent around our environment, however all without us knowing it. For example, in mining, mining is effort to explore the various potentials contained in the bowels of the earth[1].

The state takes full control of all the wealth contained in the earth and in the best use for the prosperity of the people. But in reality the people doing mining activities with no attention to important aspects at depth, such as not paying attention to the consequences caused or influence with the existence of such mining (illegal mining), but did not rule out mining is also done by mining companies that already have official permits.

The term mining law is a translation and English, that is mining law. The law of mining is: "laws governing the excavation or mining of ores and minerals in the soil ". This definition is only focused on excavation or mining activities of ores. Excavation or mining is an attempt to explore the various potentials contained in the stomach earth. In the definition this is also not seen how the relationship between the government with legal subjects. In fact, to dig the mining material is required company or agency laws that manage them.

Basically the arrangement of the management of minerals or mining fields at Indonesia, as well as the legal basis of other fields in general, that is, begins since the Dutch East Indies government Thus, up to the reign of the Old Order, in a concrete arrangement management of minerals or mining areas still using the law of Dutch East Indies products directly adopted into Indonesian mining law.

By type, the minerals, mining in Indonesia is divided into three categories: First, Mining Class A, covering strategic mineral such as: oil, natural gas, bitumen, asphalt, natural wax, anthracite, coal, uranium and other radioactive materials, nickel and cobalt. Second, Group B Mining, including vital minerals, such as gold, silver, diamond, copper, bauxite, lead, zinc and iron. Third, Group Mining C, generally mineral minerals considered to have a lower level of importance than both class other mining. Among others include various types stone, limestone, and others. Exploitation of Class minerals A is done State Company, while the company foreigners can only be involved as a partner.

While exploitation of Group minerals B can be conducted by both foreign companies and Indonesia. Exploitation of Class minerals $\mathrm{C}$ can be done by Indonesian companies as well as individual companies. As for the offender mining in Indonesia can be categorized into three, namely State, Contractor and KP holders (Mining Authority).

Along with the independence of the Republic of Indonesia, then as an independent State and sovereign leaders of the nation when it did formulation of regulatory procedures management of the mining field. But after going through various processes of debate and motion, then set mining management rules with issuance of Government Regulation. Substitute Act of Number 37 Year 1960 that set the special mining field. Almost simultaneously with the Perpu government RI at that time also issued Government Regulation in Lieu of Law No. 44 of 1960 which regulates specifically on Oil and Gas. Government Regulation in Lieu 
of Law (Perpu) Number 37 of 1960 on essentially an Indische Mijnwet 1899 (IM 1899) in the Indonesian version. That is, provisions contained in the Government Regulation in lieu of Law (Perpu) Number 37 of 1960 is an adoption of the provisions in the Indische Mijnwet 1899 (IM 1899) with authority to replace it as an example: Each said the Queen and Governor-General in Indische Mijnwet 1899 (IM 1899), respectively changed to national and government only to Perpu[2].

Furthermore, some important issues issues on mining, is policy uncertainty, illegal mining, conflicts with local communities, mining tor $\mathrm{k}$ se conflict with other sectors. D emikian also occurring in some parts of Indonesia and several more locations that exist in Indonesia that many are mining without permission resulting in good loss for the community and Country.

For the achievement of the goal it must be implemented by all components nation, including the field of criminal law enforcement. In connection with the existence of mining activities without permission of objects on the ground then the government requires a legal product in the form of a Presidential Instruction of the Republic of Indonesia Number: 3 of 2000 on Coordination of Mining Problem Resolution Without Permission. The provisions of the president instruction referred to among others Instruction to the three paragraph 1 stigmated that respect the rights of ulayat (custom) and the interests of local indigenous people in accordance with applicable legislation, paragraph 2 states to direct awareness and legal compliance of the community in conducting business activities, including business activities mining properly and legally in accordance with prevailing laws and regulations and when necessary to conduct legal repressive actions and paragraphs concerning the allocation of natural resources for local communities, this is in accordance with Law No. 32 of 2009 on Protection and Environmental Management. Article 1 paragraph (31) contents "Indigenous and tribal peoples are communities that have historically settled in a particular geographical area because of their ties to the origins of ancestors, their strong relationship with the environment, as well as a system of values that determine the economic system, political, social, and hukum " [3].

Seen from the regulation side, mining permit exploration and operation of non-metallic and rock mineral production including coal . Divided into 2 (two) namely Coal Mining Concession Working Agreement (PKP2B) whose license is issued by Central Government and Mining Authority (KP) with license from Regional Government. Since the era of regional autonomy, KP licensing has become uncontrollable as the regions are competing to issue the permit. This causes the impact of mining cases, one of which is the case of miners occurring in some areas of Indonesia. Basically, this case is already happening but the people who have around too apathetic with the impact of one of them is the recent incident occurred that there is a very deep puddle is about 20 meters caused by the former excavation of mining activities.

\section{DISCUSSION}

The world of non-metallic mineral mining and rocks in the last decade, since the recession occurred in Indonesia and the implementation of the Regional Autonomy Law began in 2001 has changed the paradigm of society so that opinions arise that eventually cause national problems with the development of mining by the community to meet the needs daily which subsequently becomes unlicensed mining entrusted by the funder, is supported by a trade system of petroleum or minerals and rocks and sand that result in consumers free to buy sand from unlicensed sand mining. Sand mining activities conducted openly (open pit) and underground mining (mine) cause environmental impact. Some impacts of environmental damage are the decrease in soil bearing capacity, decreased air quality. Coal mining with a mining system in the resulting environmental damage in the form of decline in soil surface and disruption of ground water level.

\section{A. Factors Causing the Rise of Unlicensed Mining Crime in Indonesia}

Unauthorized mining crime is a crime in a mining business conducted by an individual, a group of people, or a company / foundation incorporated as a legal entity in whose operation is not licensed by a government agency in accordance with applicable regulations, which threatens criminal sanctions for anyone who is in error the ban.

The criminal provisions on illegal mining crimes are regulated in Law No. 4 of 2009 concerning Mineral and Coal Mining, as governed by Article 158, Article 160 Paragraphs (1) and Paragraph (2), Article161, Article 163 Paragraph 1) and Paragraph (2), and Article 164.

Unlicensed mining crimes must also receive serious attention from the police, since the tasks of the Mining and Energy Agency are limited to supervision. While doing the action is the police.

The rise of mining crimes without permits / illegal mining in Indonesia is certainly encouraged or caused by several factors. The factors causing the rise of mining without permits / illegal mining in Indonesia which was collected by the author in scientific writing is as follows: [4]

\section{1) Economic factors}

Economic factors are the most vulnerable to trigger a crime. One of the factors causing the rise of illegal mining crimes in Indonesia is the economic factor. Difficult job opportunities and employment opportunities that match the level of skills or skills of the lower class. Obviously the economic factor is the main factor of a person doing mining without permission.

This is in accordance with the socialist theory proposed by Marx and Engels that "evil arises because of unbalanced economic pressures in society".

\section{2) Perpetrators want to avoid the obligations that have} been determined

One of the factors of unpopular mining in Indonesia is because the perpetrators want to avoid the obligations that have been determined by the Mining and Energy Agency and the local government, among others: production tax and levy tax (levy), LKMD, etc.

Clear that the factor of tax avoidance is the factor causing the rise of unlicensed mining / illegal mining in Indonesia. We need to know that the obligation and awareness of every citizen or legal entity in paying taxes, especially from the mining business is one of the sources of local revenue (PAD) which is allocated and allocated through APBN or APBD to finance the construction of facilities such as roads / bridges, 
health, education, shopping or salaries, and so on. It supports the surrounding community in obtaining public services in order to achieve prosperity and prosperity of the people.

\section{3) Difficult to obtain IUP (Mining Permit)}

A complicated and time-consuming process of licensing is suspected to be the cause of unauthorized mining in Indonesia. Here is one of the phrases from one of the unlicensed mining actors who successfully questioned the unauthorized mining activities in Indonesia by the author.

\section{4) Lack of socialization about the legislation}

One of the factors of rampant mining crime without permits / illegal mining in Indonesia is the lack of socialization conducted by the Mining and Energy Agency regarding legislation, regulated in Law Number 4 of 2009 on Mineral and Coal Mining as stipulated in Article 35, which reads that: the mining business is carried out in the form of IUP, IPR, and IUPK.

This means that the Mining and Energy Agency rarely or never disseminates to villages about Law No. 4 of 2009 on Mineral and Coal Mining so that some people do not know that in doing mining business must obtain permission from the authorities and if performing such activities without permission is threatened with imprisonment or fines.

\section{5) Weak law enforcement}

The weakness of law enforcement is a factor causing the rise of mining crime without permit / illegal mining in Indonesia. Weak supervision and law enforcement seem to give flexibility and not deter miners without permission. This is due to the low number of settlement of mining cases without permits / illegal mining.

Based on the actor's acknowledgment, the weakness of law enforcement is the cause of the illegal mining crime in Indonesia, namely the Police is still selective in capturing or trapping illegal mining actors. The usual modus operandi done by the perpetrator mining crime without permission :

1. Conduct mining activities beyond the given WIUP coordinates;

2. Conducting mining activities at locations that have expired IUP;

3. Conducting mining activities under the guise of new paddy fields

4. Conducting mining activities under the guise of river normalization

The impacts caused by unlicensed mining are:

1. Loss of state revenue.

2. Environmental damage.

3. Mining accident.

4. Investment climate is not conducive.

5 . Waste of mineral resources.

6. Legal harassment

7. Social vulnerability.

Other impacts due to mining activities without permission (illegal mining) such that their exploitation by digging uncontrolled manner causing environmental damage and disrupt the balance of natural ecosystems, where mining activities are carried out on farms or plantations that have high productivity.

This is very disturbing to the community because the mining activities without permits are very close to public facilities and threaten the destruction of facilities and infrastructure, such as roads and bridges, irrigation, water pollution, dust contamination, contour change, due to river sand mining, noise by carrier vehicles, and so on

Besides, the ex-location/mining concession is abandoned by illegal miners without any reclamation efforts that leave a wide and deep mudflow and potentially cause accident problems (drowning) with the casualties of children under age and other natural disasters.

\section{B. Efforts to Address the Rise of Unlicensed Mining Crime in Indonesia}

As previously stated that illegal mining illegal mining is a very serious problem considering illegal mining crimes can damage the environment and threaten the welfare of the surrounding community.

1. Police conduct socialization / legal counseling about criminal provisions concerning mining crime without permit in Law Number 4 Year 2009.

2. Installation of banners or pamphlets of each sub-district will be dangerous of unauthorized mining activities.

3. Perform routine operations on mining activities in every sub-district in Indonesia.

4. Act against illegal mining criminals in the form of imprisonment and fine.

5. Foreclosure tools used in conducting illegal mining activities.

Other efforts are:

1. Disseminating with NGOs about the dangers of mining without permission.

2. Monitoring every mining activity.

3. Provide counseling to mining communities and entrepreneurs about environmental awareness.

According to the authors of efforts of law enforcement officials and related agencies regarding the prevention of illegal mining crimes in Indonesia have been in various ways, ie preventively and repressively.

\section{1) Preventive Efforts}

In an emphasized preventive effort is to eliminate the opportunity for a crime. Preventive efforts, namely:

a. Conduct legal counsel on criminal provisions concerning mining crime without permit / illegal mining.

b. Disseminating Law No. 4 of 2009 on Mineral and Coal Mining .

c. Installation of banners / pamphlets of each district regarding the hazards of mining activities without permits / illegal mining.

d. To conduct regular supervision and operation of all mining business activities in Indonesia.

\section{2) Repressive Attempts}

This effort was made at the time of unauthorized mining crime in Indonesia in the form of law enforcement, namely:

a. To crack down on the perpetrators of mining crimes without permission and to process in accordance with applicable law. 
b. Seize tools used in mining activities without permission, both pumps and heavy equipment such as excavators and lowers.

\section{REFERENCES}

[1] Bambang Yunianto et al, "Energy Sector and Mineral Resource Policy and Its Implications for Gold Mining in Mining and Gold
Processing in Indonesia, Puslitbang of Minerals Technology and Coal, Bandung, 2004.

[2] Salim HS, Mining Law of Indonesia, Jakarta: RajaGrafindo Persada, 2007.

[3] Law Number 32 Year 2009 on Environmental Protection and Management.

[4] Law Number 4 Year 2009 On Mineral Mining And Coal 